medRxiv preprint doi: https://doi.org/10.1101/2021.04.15.21255544; this version posted April 20, 2021. The copyright holder for this preprint (which was not certified by peer review) is the author/funder, who has granted medRxiv a license to display the preprint in perpetuity.

It is made available under a CC-BY 4.0 International license .

\title{
Quantifying aerosol and droplet generation during upper and lower gastrointestinal endoscopy: whole procedure and event-based analysis
}

Frank Phillips, Jane Crowley, Samantha Warburton, George S.D. Gordon, and Adolfo Parra-Blanco

1. Frank Phillips, frankmphillips@hotmail.com

NIHR Nottingham Biomedical Research Centre, Nottingham University Hospitals NHS Trust and the University of Nottingham, Nottingham, UK orcid.org/0000-0002-1671-2390

2. Jane Crowley, Jane.Crowley@nottingham.ac.uk

Faculty of Engineering, University of Nottingham, Nottingham, UK

3. Samantha Warburton, Samantha.Warburton@nuh.nhs.uk

NIHR Nottingham Biomedical Research Centre, Nottingham University Hospitals NHS Trust and the University of Nottingham, Nottingham, UK

4. George S.D. Gordon,* George.Gordon@nottingham.ac.uk

Faculty of Engineering, University of Nottingham, Nottingham, UK

5. Adolfo Parra-Blanco, ${ }^{*}$ Adolfo.Parra-Blanco@nottingham.ac.uk

NIHR Nottingham Biomedical Research Centre, Nottingham University Hospitals NHS Trust and the University of Nottingham, Nottingham, UK orcid.org/0000-0003-2396-0226

*Corresponding authors: George.Gordon@nottingham.ac.uk and Adolfo.ParraBlanco@nottingham.ac.uk

\section{Keywords}

COVID-19, Endoscopy, Aerosols 
medRxiv preprint doi: https://doi.org/10.1101/2021.04.15.21255544; this version posted April 20, 2021. The copyright holder for this preprint (which was not certified by peer review) is the author/funder, who has granted medRxiv a license to display the preprint in perpetuity. It is made available under a CC-BY 4.0 International license .

\begin{abstract}
Objective

Aerosol generating procedures have become an important healthcare issue due to the COVID-19 pandemic, as the SARS-CoV-2 virus can be transmitted via aerosols. We aimed to characterise aerosol and droplet generation in gastrointestinal endoscopy, where there is little evidence.
\end{abstract}

\title{
Design
}

This prospective observational study included patients undergoing routine per-oral gastroscopy (POG, $n=36)$, trans-nasal endoscopy (TNE, n=11) and lower gastrointestinal (LGI) endoscopy ( $n=48$ ). Particle counters took measurements near the appropriate orifice (two models used, diameter ranges $0.3 \mu \mathrm{m}-25 \mu \mathrm{m}$ and $20 \mu \mathrm{m}-3000 \mu \mathrm{m})$. Quantitative analysis was performed by recording specific events and subtracting the background particles.

\section{Results}

POG produced 2.06x the level of background particles $(p<0.001)$, and $2.13 x$ the number of particles compared to TNE. LGI procedures produce significant particle counts $(p<0.001)$, with a rate of $8.8 \times 10^{6} / \mathrm{min} / \mathrm{m}^{3}$ compared to $13.0 \times 10^{6} / \mathrm{min} / \mathrm{m}^{3}$ for POG. Events significant relative to the noise floor of background particles were: POG- throat spray $(112.3 x, p<0.01)$, oesophageal extubation (36.7x, $p<0.001)$, coughing/gagging (30.7x, $p<0.01)$; TNE- nasal spray $(32.8 x, p<0.01$ ), nasal extubation (25.6x, $p<0.01$ ), coughing/gagging (23.3x, $p<0.01)$; LGI- rectal intubation $(3.5 x, p<0.05)$, rectal extubation $(11.8 x, p<0.01)$, application of abdominal pressure $(4.9 x, p<0.05)$. These all produced particle counts larger than or comparable to volitional cough.

\section{Conclusions}

Gastrointestinal endoscopy performed via the mouth, nose or rectum all generates significant quantities of aerosols and droplets. As the infectivity of procedures is not established, we therefore suggest adequate PPE is used for all Gl endoscopy where there is a high population prevalence of COVID-19. Avoiding throat and nasal spray would significantly reduce particles generated from UGI procedures. 
medRxiv preprint doi: https://doi.org/10.1101/2021.04.15.21255544; this version posted April 20, 2021. The copyright holder for this preprint (which was not certified by peer review) is the author/funder, who has granted medRxiv a license to display the preprint in perpetuity. It is made available under a CC-BY 4.0 International license .

\section{SIGNIFICANCE OF THIS STUDY}

\section{What is already known on this subject?}

The way we deliver healthcare has dramatically changed since the start of the COVID-19 pandemic. This includes gastrointestinal endoscopy, with precautions in place such as enhanced personal protective equipment, ventilation standards and prioritisation of procedures. Little research has been performed on establishing endoscopy as an aerosol generating procedure (AGP). Two recent studies indicate per-oral gastroscopy is an AGP. However, there is no data on the causative events within procedures, limited particle size analysis, and no data on trans-nasal endoscopy (TNE) or lower gastrointestinal (LGI) endoscopy.

\section{What are the new findings?}

This study greatly expands our knowledge of aerosol and droplet generation during gastrointestinal endoscopy. We show that per-oral gastroscopy (POG), TNE and LGI endoscopy all produce aerosols and droplets. We have quantified this to show that POG produces double the amount of background particles, whilst TNE produces half the particles and LGI a third lower particles than POG per unit time. We use a novel subtraction technique to analyse individual events within endoscopic procedures. This shows that anaesthetic spray is the major contributor for upper gastrointestinal (UGI) endoscopy, followed by coughing/gagging as well as extubation. For LGI endoscopy, the main contributors are rectal extubation, abdominal pressure application and rectal intubation, which produce more particles in the droplet range. All these events are at least comparable to volitional cough, whilst anaesthetic throat spray produces particle counts ten times higher. Furthermore, the presence of a hiatus hernia appears to increase particle generation for UGI endoscopy, whilst high patient discomfort does this for LGI endoscopy. Lastly, we show that particles sizes of some events, such as oral and rectal extubation, are significantly greater than the average particle size of a volitional cough. We also use a spray characteriser to show that particles of up to $300 \mu \mathrm{m}$ are produced in UGI extubation and fundal retroflexion.

\section{How might it impact on clinical practice in the foreseeable future?}

The results in this study give important information for how we deliver endoscopy when there is a threat to the safety of healthcare workers and patients from transmissible infections. It is therefore relevant not only for the current COVID-19 pandemic, but also for other potential respiratory and gastrointestinal pathogens. As the infectivity of procedures is not established, we therefore suggest adequate PPE is used for all GI endoscopy where there is a high population prevalence of COVID-19. We show that for UGI endoscopy, alternatives to local anaesthesia spray would significantly reduce aerosol and droplet generation. The use of TNE would be desirable as it produces less aerosols than POG, but still additional mitigating strategies would be required. For LGI endoscopy, good technique that limits patient discomfort may mitigate aerosol and droplet generation. Further research needs to be done on infectivity of endoscopic procedures and barrier mitigating devices. 
medRxiv preprint doi: https://doi.org/10.1101/2021.04.15.21255544; this version posted April 20, 2021. The copyright holder for this preprint (which was not certified by peer review) is the author/funder, who has granted medRxiv a license to display the preprint in perpetuity. It is made available under a CC-BY 4.0 International license .

\section{INTRODUCTION}

Severe acute respiratory syndrome coronavirus 2 (SARS-CoV-2), the cause of the ongoing coronavirus 2019 (COVID-19) pandemic, can be transmitted via aerosols. ${ }^{1-3}$ Aerosol generating procedures (AGPs) therefore represent a transmission risk to healthcare workers and have become an important healthcare issue.

An aerosol contains solid or liquid particles small and light enough to remain suspended in the air for long periods of time. ${ }^{4}$ Aerosols are in the respirable range, meaning they can deposit in the lower airways to cause infection via airborne transmission. ${ }^{4}$ In contrast, droplets are larger and gravitationally settle rapidly or can be inhaled at close contact. The World Health Organization (WHO) have defined aerosols as particles $<5 \mu \mathrm{m}$ and droplets as $\sim 5-10 \mu \mathrm{m} .{ }^{5}$ However, under certain conditions, particles larger than $10 \mu \mathrm{m}$ can remain airborne for extended periods of time. ${ }^{6}$

The definition of an AGP lacks consensus: the WHO defines this as any medical procedure that can induce the production of aerosols of various sizes, including particles $<5 \mu \mathrm{m} .{ }^{5}$ However, Public Health England only considers AGP those resulting in release of airborne particles from the respiratory tract. ${ }^{7}$ Further difficulty with definitions arises since heavy breathing, talking, coughing, and singing all generate particles of varying sizes including aerosols. ${ }^{8-9}$

The WHO has produced a list of AGPs mainly based on evidence from small retrospective epidemiological studies linking these procedures with greater risk for healthcare worker infections. ${ }^{10}$ Aerosol or droplet levels were not measured in these studies, so the exact mode of transmission was not known. Although Gl endoscopy is not on this list, various professional societies have designated upper GI endoscopy as an AGP, and LGI endoscopy at least of uncertain risk status, based on theoretical grounds. ${ }^{11-14}$ This has had important repercussions, including postponed procedures, lost capacity, and the use of enhanced PPE.

Two recent studies have provided evidence of aerosol generation during upper gastrointestinal (UGI) endoscopy using handheld particle counters. Chan et al showed that aerosols are generated during UGI endoscopy, and that continuous suction reduced aerosols, whilst level of sedation had little effect. ${ }^{15}$ Sagami et al showed that aerosols increased significantly in a plastic enclosure around patients' heads during UGI endoscopy compared with a control group. ${ }^{16}$

Our study aims to characterise aerosol and droplet generation in gastrointestinal endoscopy performed via the mouth, nose or rectum, by quantifying particles across whole procedures and specific events during procedures, and analysing associated risk variables. This information is important in ensuring the safety of Gl endoscopy for patients and healthcare workers for both current and future respiratory and gastrointestinal pathogens. 
medRxiv preprint doi: https://doi.org/10.1101/2021.04.15.21255544; this version posted April 20, 2021. The copyright holder for this preprint (which was not certified by peer review) is the author/funder, who has granted medRxiv a license to display the preprint in perpetuity. It is made available under a CC-BY 4.0 International license .

\section{MATERIALS AND METHODS}

\section{Study design and participants}

This is a prospective observational study. Health Research Authority and ethical approval was granted by the Wales Research Ethics Committee prior to the start of the study. We included patients undergoing routine upper and lower GI endoscopy on the lists of thirteen different participating endoscopists at the Endoscopy unit of the Nottingham University Hospitals NHS Trust Treatment Centre between October 2020-March 2021. The inclusion criteria were adult patients $>18$ years with capacity to consent. Before the procedure, participants were given an explanation and a patient information sheet by a dedicated research nurse (see Supplementary Information), with at least 24 hours to consider their participation. During the consent process, capacity was assessed for the procedure and for participation in the study. Written consent was documented on a patient consent form.

Procedures were performed as they normally would be in clinical practice. Patients chose whether they wanted sedation and endoscopists chose whether they wanted to use carbon dioxide only or water-immersion for insertion during LGI procedures. All UGI procedures were performed with $\mathrm{CO}_{2}$ or air for insufflation and intermittent suctioning was used for all per-oral gastroscopies (POG).

From limited previous studies of particle size distribution in coughing and sneezing we determined that with 5 replicates per patient we can detect an effect size (Cohen's $d$ ) of 1.98 , which is sufficient to differentiate between a cough and sneeze. ${ }^{17-18}$ We therefore planned to conduct at least 5 replicates of the following UGI endoscopic procedures: 1) POG with throat spray only (i.e. unsedated), 2) POG with conscious sedation (using midazolam \pm fentanyl), 3) TNE; and 5 replicates of the following $\mathrm{LGI}$ procedures: 1) $\mathrm{CO}_{2}$-assisted insertion, 2) water-assisted insertion , 3) conscious sedation (using midazolam + fentanyl), 4) unsedated, 5) therapeutic procedures.

To standardise the procedures, we used endoscopy rooms within the same endoscopy suite, which all had room ventilation set at 15-17 air changes per hour, and a similar size, air temperature and humidity levels. We minimized unnecessary airflow for example by not allowing the room doors to be opened during the procedures and only allowing one additional person (the research nurse) in the room. All present in the room wore enhanced PPE which minimised the contribution of additional human aerosol sources.

\section{Patient and public involvement}

The Nottingham University Hospitals' NHS Trust hosts an NIHR Gastrointestinal \& Liver Biomedical Research Centre, through which a Patient Advisory Group has been formed. Three members of this group were recruited to approve the significance of the study and acceptability of the methodology. They also ensured the Patient Information Sheet and Consent form were easily understandable.

\section{Measurement methodology}

We used two pieces of equipment to measure particle sizes. The first was a TSI AeroTrak Portable Particle Counter (models 9310-02 and 9500-01) which previous studies have used for respirable particle sizing in medical contexts. ${ }^{19}$ The latter model, used for the majority of procedures measured particles in six diameter ranges $(0.5-0.7 \mu \mathrm{m}, 0.7-1.0 \mu \mathrm{m}, 1.0-3.0 \mu \mathrm{m}, 3.0-5.0 \mu \mathrm{m}, 5.0-$ 
medRxiv preprint doi: https://doi.org/10.1101/2021.04.15.21255544; this version posted April 20, 2021. The copyright holder for this preprint (which was not certified by peer review) is the author/funder, who has granted medRxiv a license to display the preprint in perpetuity. It is made available under a CC-BY 4.0 International license .

$10.0 \mu \mathrm{m}, 10.0-25 \mu \mathrm{m}$ ) and has a flow rate of $100 \mathrm{~L} / \mathrm{min}$. A $2 \mathrm{~m}$ tube (manufacturer provided) was connected to an isokinetic inlet head placed $10 \mathrm{~cm}$ from the mouth for UGI procedures and approximately $20 \mathrm{~cm}$ from the anus in LGI procedures using an articulating arm. The effect of the tube length on larger particles is accounted for by a calibration experiment in a room at equilibrium using a $0.02 \mathrm{~m}$ tube. The second instrument used was an Oxford Lasers VisiSize N60 Spray Characterisation Tool which was used in four POGs. Spray characterisers have previously been used for characterising coughs and sneezes. ${ }^{17}$ The configuration we used allows sizing of particles from $\sim 10 \mu \mathrm{m}$ to $3.5 \mathrm{~mm}$ diameter. The instrument images particles that pass through a small volume located between a laser head and a camera (dimensions $12.6 \times 7.2 \times 50 \mathrm{~mm}=$ $\left.4536 \mathrm{~mm}^{3}\right)$. The instrument is placed such that this volume is located $10 \mathrm{~cm}$ from the mouth of the patient (see Supplementary Information).

During the procedure, an observation camera with a timestamp feature is used to record audio and video for synchronisation purposes. For each procedure, an experienced research nurse recorded information on a case report form containing demographics (age, sex, BMI) and variables determined during the procedure (sedation type, degree of discomfort, use of CO2 or water for LGI procedures, subjective estimate of anal tone and presence of hiatus hernia). During the procedure, the times of relevant events, beginning when the patient has entered and ending after they have left, are recorded along with the time in seconds. A template is given in the Supplementary Information. Periods of time when there are no significant events, e.g. lengthy examinations without patient movement, are identified and marked as 'null reference' events.

\section{Data processing and statistical analysis}

\section{Analysis of full procedure data}

We first consider the total particle count across each procedure for 3 particle diameter ranges: 0.5$5 \mu \mathrm{m}, 5-25 \mu \mathrm{m}$, and $0.5-25 \mu \mathrm{m}$ with patient position changes suppressed. The time period considered starts from either anaesthetic spray (UGI) or intubation (LGI) and ends at extubation. This is compared to a reference window before the procedure starts and is normalised to account for different durations (see Supplementary information).

\section{Causal event-based model}

We next apply our causal event-based model. For each annotated event, we estimate the room background immediately before the event and subtract this from the raw count immediately after the event to estimate the amount of aerosol produced by the event (see Supplementary Information).

\section{Statistical analysis}

Building on existing models of aerosol production in the respiratory $\operatorname{tract}^{20}$ we use a log-normal distribution to model the distribution of total particle counts across different instances of each event. For the whole procedure data, a $t$-test is applied, but because the causal event model takes a difference, a sum of a log-normal and normal distribution is used and $p$-values are computed using rejection sampling (see Supplementary Information). 
medRxiv preprint doi: https://doi.org/10.1101/2021.04.15.21255544; this version posted April 20, 2021. The copyright holder for this preprint (which was not certified by peer review) is the author/funder, who has granted medRxiv a license to display the preprint in perpetuity. It is made available under a CC-BY 4.0 International license .

\section{RESULTS}

\section{Demographics}

Overall, we recorded 47 UGI procedures (36 per-oral, 11 trans-nasal) and 48 LGI procedures (37 colonoscopies, 11 flexible sigmoidoscopies). Of the UGI procedures, 12 performed a volitional cough, deep breathing and speaking for reference. Patient variables were as follows. Sex: 51 male, 44 female. Age: range 23-93, median 62 years. BMI: range 16.3-56, median 25.5. Sedation: UGI: 15 midazolam \pm fentanyl, 32 unsedated, all procedures used xylocaine throat or nasal spray, LGI: 19 midazolam \pm fentanyl, 24 Entonox, 4 no sedation. Anal tone: 5 low, 21 medium, 14 high, 8 not recorded. LGI use of $\mathrm{CO}_{2}$ vs water: $42 \mathrm{CO}_{2}, 6$ water. Discomfort: 56 low, 33 medium, 3 high, 4 not recorded. UGI hiatus hernia: yes 24, no 23. Smoker: 16 yes, 80 no. LGI diverticular disease: 40 none, 4 mild, 4 extensive.

\section{Whole procedure analysis}

Over the full range of particle sizes $(0.5-25 \mu \mathrm{m})$ and normalised to procedure duration, POG produced significantly higher particle counts than the reference background $(2.06 \mathrm{x}, 95 \% \mathrm{Cl}: 1.73-$ 2.45, $p<0.001, \mathrm{n}=36)$ as did TNE $(1.99 \mathrm{x}, 95 \% \mathrm{Cl}: 1.51-2.63, p<0.001, \mathrm{n}=11)$. However, directly comparing POG and TNE, we find that POG produces significantly more particles $(2.13 \mathrm{x}, 95 \% \mathrm{Cl}: 1.4-$ 3.2, $\mathrm{p}<0.001$ ). LGI procedures (with patient position changes excluded) were significantly higher than the reference background $(1.34 \mathrm{x}, 95 \% \mathrm{Cl}: 1.14-1.59, p<0.001, \mathrm{n}=48)$, but less so than UGI procedures. The absolute number of particles is on average less for POG than for LGI procedures $\left(0.71 \times 10^{8}\right.$ vs $\left.1.69 \times 10^{8}\right)$, but is greater when procedure duration (intubation to extubation) is taken into account: POG produce particles at a rate of $13.9 \times 10^{6}\left(95 \% \mathrm{Cl}: 7.3 \times 10^{6}-20.5 \times 10^{6}\right)$ per minute $/ \mathrm{m}^{3}$ vs $8.8 \times 10^{6}\left(95 \% \mathrm{Cl}: 4.0 \times 10^{6}-13.6 \times 10^{6}\right)$ per minute $/ \mathrm{m}^{3}$ for LGI procedures excluding position changes. The median duration of recorded procedures is 7.2 mins for UGI and 24.7 mins for LGI.

For particles $>5 \mu \mathrm{m}$ in diameter we find that LGI procedures are no longer significant relative to the background $(p=0.082)$. For particles $<5 \mu \mathrm{m}$ in diameter we find all procedure types are significantly higher than reference background (POG: 1.99x, TNE: 2.09x, LGI: $1.34 \mathrm{x}, p<0.001)$. The particle counts, normalised to procedure duration, relative to the reference background are summarised in Figure 1.

Regarding variables, the only significant result for LGI procedures was patient discomfort rated 'high' resulted in more particles than discomfort rated 'low' (6.3x,95\%Cl:1.6-25.3, p<0.01). Other variables, including age, $\mathrm{BMI}$, use of sedation, use of $\mathrm{CO}_{2}$ or water for insertion etc. were not found to have significant effect. 
medRxiv preprint doi: https://doi.org/10.1101/2021.04.15.21255544; this version posted April 20, 2021. The copyright holder for this preprint (which was not certified by peer review) is the author/funder, who has granted medRxiv a license to display the preprint in perpetuity.

It is made available under a CC-BY 4.0 International license .
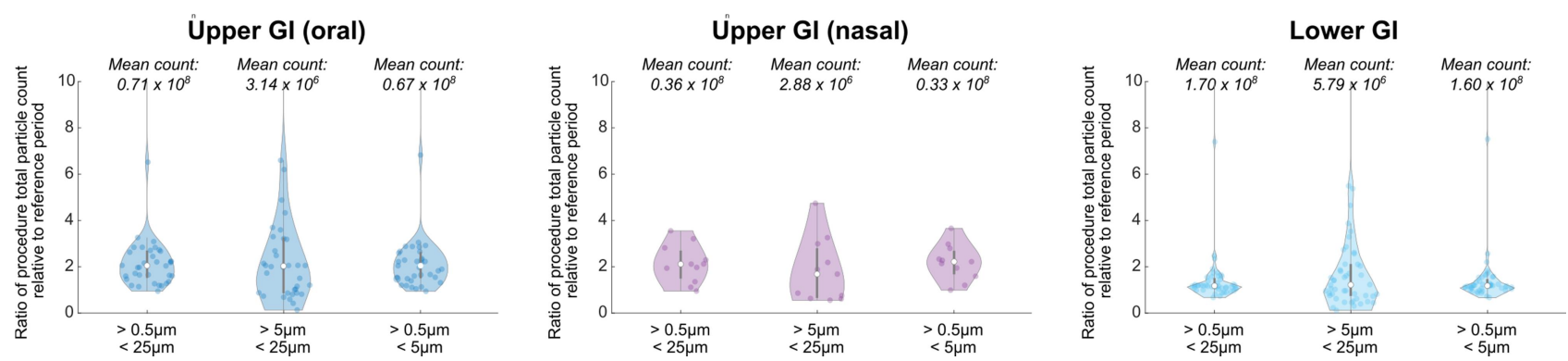

Figure 1: Ratios of particle counts over whole procedures relative to a reference period before the start of the procedure (normalised to procedure duration). White circles indicate median values. Raw mean counts (not normalised to procedure duration) are shown above.

\section{Maximum particle generating events}

We next determined the nearest event preceding each maximum count in a procedure, shown in Fig.2. For POG over the full particle size range, the most common maximum particle generating events were: anaesthetic throat (57\% of procedures), oral extubation (19\%) and coughing/gagging (11\%). However, we note that coughing/gagging only occurs during some procedures so is likely under-represented. For TNE, these were: application of nasal spray (55\%), cough (18\%) and intubation (9\%). For LGI procedures, these were rectal extubation (39\%) and intubation (11\%). For LGI many maximum events are 'not recorded', likely due to imperfect exclusion of position changes.

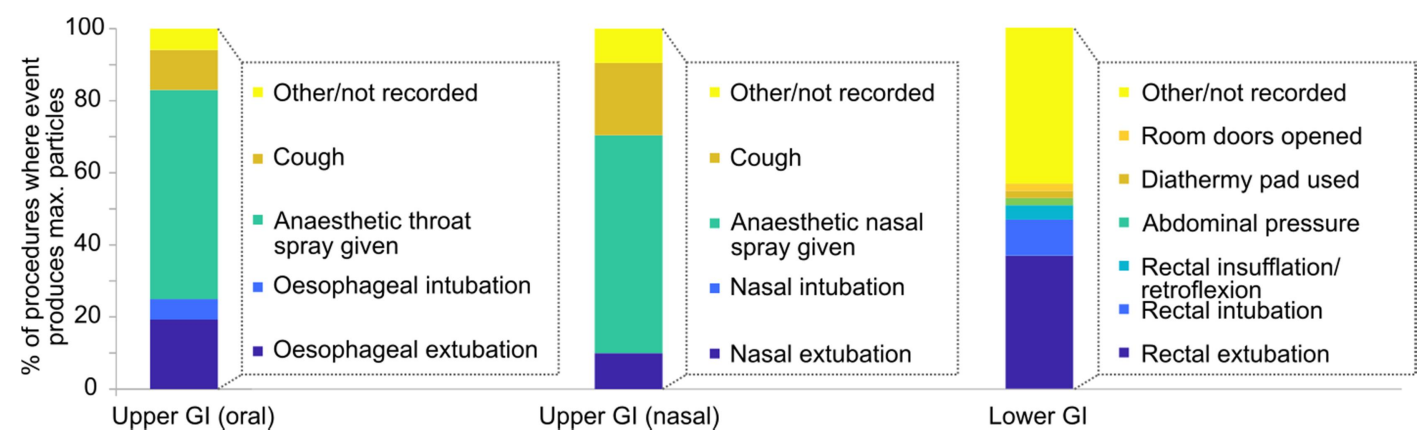

Figure 2: Event associated with maximum particle generation over a procedure. \% represents number of procedures for which that event immediately precedes the maximum particle count.

\section{Causal event-based analysis}

We next consider individual events, shown in Fig.3 (UGI) and Fig.4 (LGI). For UGI procedures we find the following events significant relative to the noise floor: nasal intubation (16.3x, 95\%Cl:1.6308.6, $p<0.05, \mathrm{n}=11$ ), oral extubation (36.7x, 95\%Cl:7.4-570.5, $p<0.001, \mathrm{n}=38$ ), nasal extubation (25.6x, 95\% Cl:3.3-435.5, $p<0.01, \mathrm{n}=11)$, coughing/gagging during oral endoscopy (30.7x, 95\% Cl:4.9-530.9, $p<0.01, \mathrm{n}=26)$, coughing/gagging during TNE $(23.3 \mathrm{x}, 95 \% \mathrm{Cl}: 3.2-425.3, p<0.01$, $\mathrm{n}=17)$, forced coughing $(8.0 \mathrm{x}, 95 \% \mathrm{Cl}: 0.7-150.9, p<0.05, \mathrm{n}=12)$, deep breathing $(15.9 \mathrm{x}, 95 \% \mathrm{Cl}: 1.6-$ 310.6, $p<0.05, \mathrm{n}=12)$, anaesthetic nasal spray $(32.8 \mathrm{x}, 95 \% \mathrm{Cl}: 4.0-533.1, p<0.01, \mathrm{n}=11)$, anaesthetic throat spray $(112.3 \times 95 \% \mathrm{Cl}: 13.3-1929.9, p<0.01, \mathrm{n}=35)$. Oral intubation is not significant $(p=0.275$, $\mathrm{n}=36)$. Speaking at low volume is not significant relative to the reference $(p=0.260, n=13)$, which is consistent with previous studies. ${ }^{6}$

For LGI procedures we find several events that are significant relative to the noise floor: rectal intubation (3.5x, 95\% Cl:1.1-20.9, $p<0.05, \mathrm{n}=45)$, rectal extubation $(11.8 \mathrm{x}, 95 \% \mathrm{Cl}: 3.1-71.0, p<0.01$, 
medRxiv preprint doi: https://doi.org/10.1101/2021.04.15.21255544; this version posted April 20, 2021. The copyright holder for this preprint (which was not certified by peer review) is the author/funder, who has granted medRxiv a license to display the preprint in perpetuity.

It is made available under a CC-BY 4.0 International license .

$\mathrm{n}=44)$, application of abdominal pressure $(4.9 \mathrm{x}, 95 \% \mathrm{Cl}: 1.0-31.1, p<0.05, \mathrm{n}=24)$, and patient position changes $(16.6 \mathrm{x}, 95 \% \mathrm{Cl}: 6.6-84.7, p<0.001, \mathrm{n}=98)$. We observe that rectal extubation produces significantly more particles than intubation $(3.3 \mathrm{x}, 95 \% \mathrm{Cl}: 1.1-8.6, p<0.05)$. Biopsy sampling, insertion/removal of catheters, rectal insufflation/retroflexion and the use of diathermy cutting are not significant for any of the size ranges.

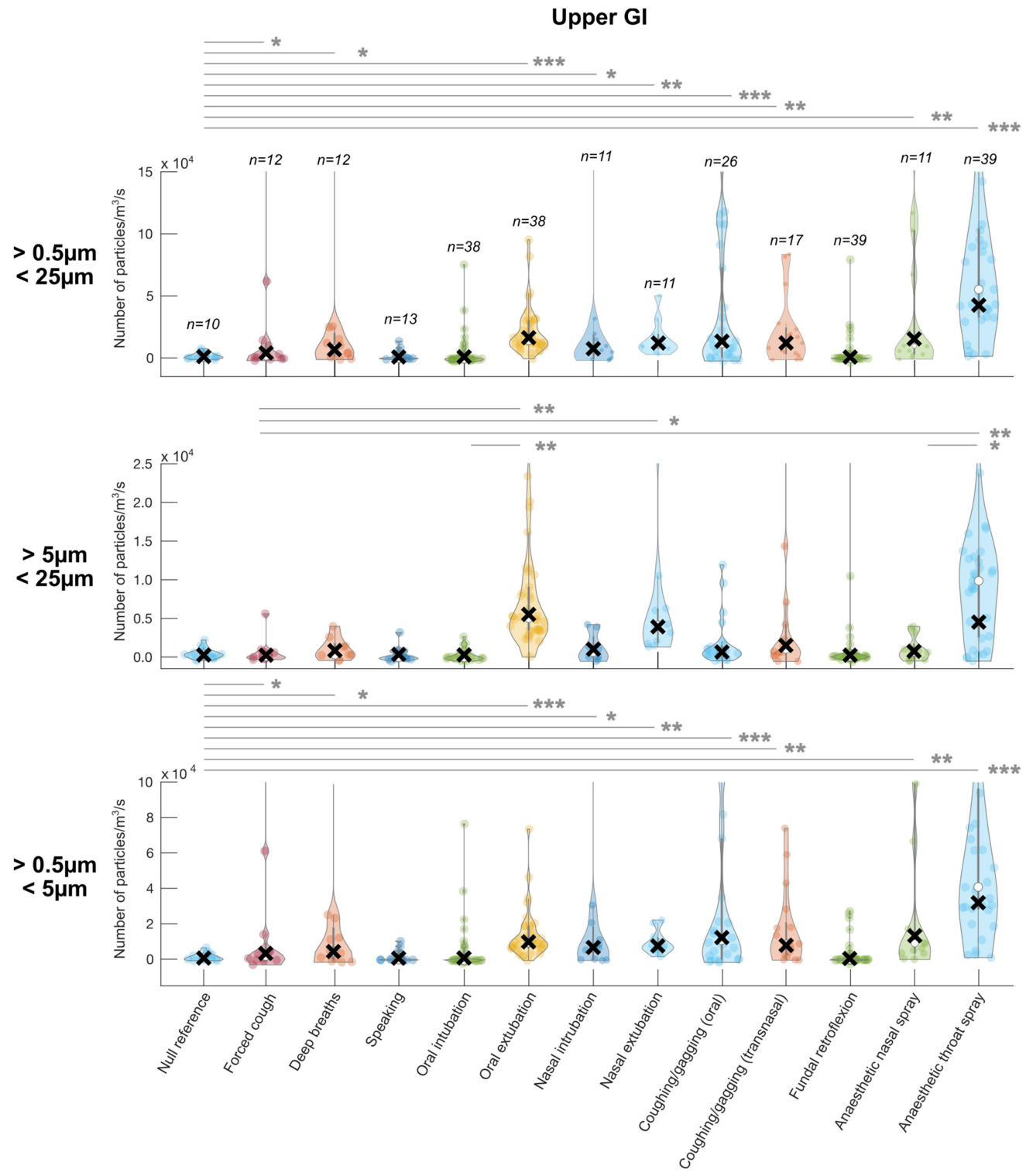

Figure 3: Particle production by individual events measured during upper GI procedures. Numbers of recorded events are given above. Black crosses represent means and white circles represent medians. $*=$ $p<0.05, * * p<0.01, * * * p<0.001$. For readability, only a selection of salient statistical relationships are shown. 
medRxiv preprint doi: https://doi.org/10.1101/2021.04.15.21255544; this version posted April 20, 2021. The copyright holder for this preprint (which was not certified by peer review) is the author/funder, who has granted medRxiv a license to display the preprint in perpetuity.

\section{Lower GI}
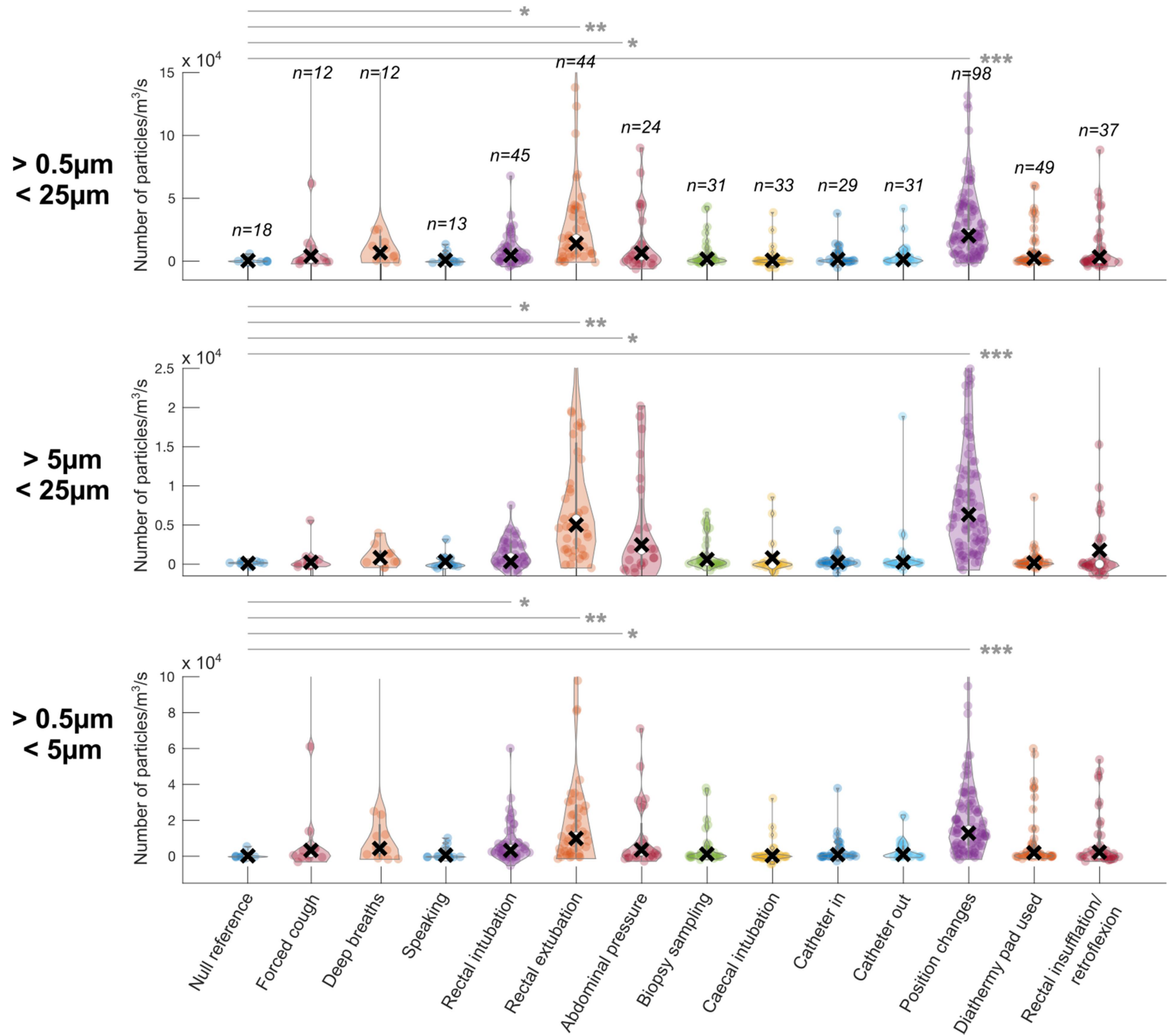

Figure 4: Particle production by individual events measured during lower GI procedures. Forced cough, deep breaths and speaking are replicated to aid comparison. Numbers of recorded events are given above. Black crosses represent means and white circles represent medians. $*=p<0.05, * *$ $p<0.01, * * * p<0.001$. For readability, only a selection of salient statistical relationships is shown.

\section{Comparison to volitional coughing}

To examine the relevance for potential airborne pathogen spread, we next compare the events to volitional coughing (Table 1 in Supplementary), in line with previous work. ${ }^{6}$ For UGI procedures, we find the following events statistically indistinguishable from the mean volitional cough: nasal extubation ( $p=0.068)$, coughing/gagging during oral $(p=0.082)$, coughing/gagging during transnasal $(p=0.253)$, deep breaths $(p=0.352)$, speaking $(p=0.077)$, anaesthetic nasal spray $(p=0.227)$. However, some events produce significantly more particles: oral extubation (3.9x, 95\% Cl:1.1-30.2, $p<0.05)$ and anaesthetic throat spray $(10.5 x, 95 \% \mathrm{Cl}: 1.2-80.1, p<0.05)$.

For LGI procedures particle generation is comparable to a forced cough for intubation $(p=0.466)$, extubation $(p=0.063)$ and abdominal pressure $(p=0.338)$, but position changes produce significantly more particles $(4.7 x, 95 \% \mathrm{Cl}: 1.3-25.0, p<0.01)$. 
medRxiv preprint doi: https://doi.org/10.1101/2021.04.15.21255544; this version posted April 20, 2021. The copyright holder for this preprint (which was not certified by peer review) is the author/funder, who has granted medRxiv a license to display the preprint in perpetuity.

It is made available under a CC-BY 4.0 International license .

\section{Particle size analysis}

The size range of particles associated with each event is shown in Fig.5. For UGI procedures, oral extubation produces particle sizes significantly larger than volitional coughing $(2.3 \mu \mathrm{m}$ vs $0.53 \mu \mathrm{m}$, $p<0.001$ for both), whilst particle sizes are similar for involuntary coughing/gagging (oral: $0.30 \mu \mathrm{m}$, $p=0.17$, nasal: $0.41 \mu \mathrm{m}, p=0.27)$. Nasal extubation is statistically comparable to oral extubation $(p=0.06)$, but only marginally; more data may show a difference. By contrast, nasal intubation produces smaller particles comparable in size to volitional coughing $(0.51 \mu \mathrm{m}, p=0.492)$. The mean particle diameters for deep breathing and speaking are also small $(0.28 \mu \mathrm{m}$ and $0.48 \mu \mathrm{m})$, consistent with previous studies. ${ }^{21}$ Both anaesthetic throat spray $(p=0.08)$ and nasal spray $(p=0.27)$ produce particles statistically similar in size to coughing. For LGI procedures, rectal extubation produces particles of a similar mean size to oral extubation $(2.56 \mu \mathrm{m}, p=0.226)$. Position changes of the patient produces particles comparable to rectal extubation $(2.1 \mu \mathrm{m}, p=0.16)$.
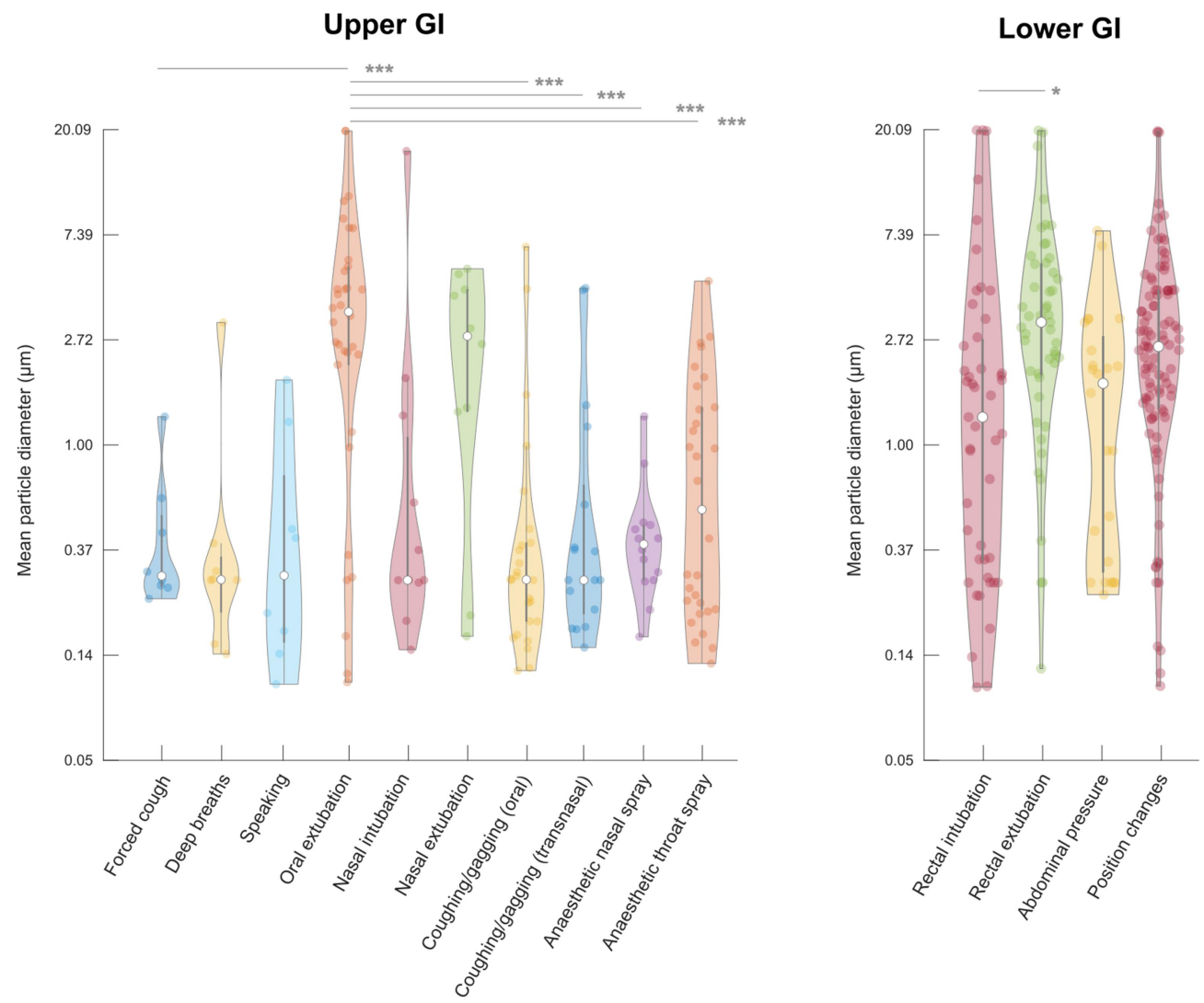

Figure 5: Particle size distribution for statistically significant particle generating events. * $=$ $p<0.05, * * p<0.01, * * * p<0.001$. Note that for readability, only a small selection of salient statistical relationships are shown.

To examine the effect of larger particles, we used a spray characteriser (Fig. 1 in Supplementary) to record four separate POGs. For the cases examined, we found that oral extubation and fundal retroflexion can produce particles up to $300 \mu \mathrm{m}$ (mean measured diameter $32 \mu \mathrm{m}$ ), whilst coughing/gagging does not (see Supplementary Information).

\section{Impact of variables}

Finally, we analyse the effect of measured variables on event-based particle production. In the presence of a hiatus hernia, there was a much larger increase in particle generation during coughing/gagging $(33.6 \mathrm{x}, p<0.05)$ and volitional coughing $(31.0 \mathrm{x}, p<0.05)$. For UGI, there is limited impact of variables on particle size. 
medRxiv preprint doi: https://doi.org/10.1101/2021.04.15.21255544; this version posted April 20, 2021. The copyright holder for this preprint (which was not certified by peer review) is the author/funder, who has granted medRxiv a license to display the preprint in perpetuity.

It is made available under a CC-BY 4.0 International license .

For LGI procedures, the variables have minimal effect on rectal intubation and rectal extubation: sedation, anal tone and age are not statistically significant. For abdominal pressure, higher anal tone produces more particles $(4.6 x, p<0.05)$. 
medRxiv preprint doi: https://doi.org/10.1101/2021.04.15.21255544; this version posted April 20, 2021. The copyright holder for this preprint (which was not certified by peer review) is the author/funder, who has granted medRxiv a license to display the preprint in perpetuity. It is made available under a CC-BY 4.0 International license .

\section{DISCUSSION}

This is the first study to report that both TNE and LGI endoscopy are aerosol and droplet generating, and we can confirm the results from previous studies showing that POG is an AGP. We are also the first to report on defined particle generating events and associated particle sizes within procedures performed via the mouth, nose and rectum. Both POG and TNE should therefore be classed as AGPs, whilst the classification of LGI endoscopy depends on the definition of AGP used.

Our primary instrument of measurement has been the particle counter. The superior flow rate of the particle counter in our study (up to $100 \mathrm{~L} / \mathrm{min}$ ) likely provides a greater accuracy than the handheld particle counters (3L/min) used in other studies, ${ }^{15-16}$ and has the advantage of rapidly clearing generated particles, thus allowing accurate measurements of subsequent events. A central problem with any study measuring particles is the high levels of background particles, which are present even in well ventilated rooms such as our endoscopy suites. One solution is to use highly ventilated laminar flow 'clean rooms,' ${ }^{21}$ but this may lead to under-representation if particles are removed by the ventilation system rather than being recorded. We have therefore devised a novel method of analysing the data, by subtracting the background level of particles, which can be used for 'real-life' procedures. This allows us to measure a range of procedural events producing large spikes in particles, which would be the most relevant for potential infectivity. The limitation is that this approach has an effective 'noise floor', determined by fluctuations in the background particle counts, meaning that smaller spikes may not reveal themselves. Additionally, we use a spray characteriser instrument that allows us to observe particles up to $3000 \mu \mathrm{m}$ in size, greatly expanding the size range compared to previous work.

With regards to POG, our results confirm those of previous studies showing this is an AGP. We have quantified this, showing that POG produces particles at double the background level of particles. The most significant contributing event is local anaesthetic throat spray application, which generates ten times the number of particles compared to a volitional cough, with an average particle size in the aerosol range. By comparison, a recent study showed that controlled endotracheal intubation and extubation in asymptomatic patients generate only a fraction of the aerosols generated by volitional coughing. ${ }^{21}$ The particles recorded with throat spray application are potentially infectious, as they would have rebounded from the patient's oropharynx or occasionally, been contributed by coughing induced by the throat spray. There is additional risk because the throat spray is applied face-on with the patient. It is therefore important that barrier methods such as face shields or goggles are used whilst applying throat and nasal spray. Simply avoiding the use of throat spray would completely remove this significant source of particles, although the subsequent need for sedation would lead to reduced patient choice and additional recovery time.

Extubation is the second most particle generating event in POG and is also significantly more particle generating than volitional cough. However, a higher proportion of particles is in the droplet range (and reaches up to $3000 \mu \mathrm{m}$ ), which has a lower risk for airborne transmission. This is understandable as both insufflation in the oesophagus and the movement of the wet shaft of the endoscope on extubation will generate particles. ${ }^{8}$ Coughing/gagging are also significant generators of particles, and is predictably comparable to the level of particles produced by volitional coughing, although we did not find that the use of sedation reduced particle counts over the whole procedure. The usefulness of suctioning, described by Chan et $a l,{ }^{15}$ cannot be commented on in our study, as intermittent suctioning was applied in all of our cases. 
medRxiv preprint doi: https://doi.org/10.1101/2021.04.15.21255544; this version posted April 20, 2021. The copyright holder for this preprint (which was not certified by peer review) is the author/funder, who has granted medRxiv a license to display the preprint in perpetuity. It is made available under a CC-BY 4.0 International license .

Interestingly, during both UGI procedures and volitional coughing, we found the presence of a hiatus hernia gives increased levels of particles, with an average size in the aerosol range. This may be due to the loss of the physiological lower oesophageal sphincter, which would enable aerosols to be expelled unimpeded from the stomach and out of the mouth as abdominal muscles are contracted during coughing.

TNE has been suggested by some as a non-AGP method for performing UGI endoscopy, although the generation of aerosols from intranasal application of spray has already been suggested. ${ }^{22-23}$ Our results show that TNE is an AGP and produces particles predominantly in the aerosol range, which may also have implications for similar otolaryngology procedures. Nasal spray application, nasal intubation and nasal extubation were all associated with significant spikes of particles. TNE generates approximately half the level of particles than POG; therefore, if used with additional mitigating strategies (avoidance of nasal spray, barrier methods) TNE could potentially become a non-AGP procedure.

With regards to LGI endoscopy, our study shows the absolute levels of particles produced are greater than UGI procedures, but are about one third lower when taken per unit time. Although there would be a greater exposure to aerosols in LGI procedures due to longer procedures, these are therefore more likely to be cleared in well ventilated rooms. We recognise that COVID-19 is primarily a respiratory pathogen, and faeco-oral transmission has not been proved. The risk from LGI procedures is likely to be considerably lower than equivalent aerosols generated by UGI procedures. However, it should be noted that infection of intestinal cells and viral replication has been shown, ${ }^{23}$ and SARS-Cov-2 RNA has been detected in stools, ${ }^{24}$ whilst there are also implications for other types of gastrointestinal pathogens. There have been attempts to mitigate aerosol and droplet diffusion during colonoscopy using specially designed shorts with a diaphragm to pass the colonoscope. ${ }^{25}$

An important source of interference to consider for LGI endoscopy occurs during patient position changes. We observe that turning a patient in the bed before the procedure has even started results in a large spike in measured particles, which is probably due to air movement and the rubbing of materials. This would explain the larger particle sizes for this particular event. The clinical relevance of position changes is therefore difficult to interpret. Fortunately, due to the enhanced suction flows of our particle counter, particle counts rapidly return to baseline after position changes, so do not interfere with readings of subsequent events.

We found that more particles are generated across the whole procedure if significant discomfort was reported (independently rated by the research nurse). This is likely due to looping or excess $\mathrm{CO}_{2}$ insufflation during the procedure. Water assisted insertion however, which aims to reduce looping and discomfort, was not associated with lower particle counts. However, this study was not powered to test the effect of water-assisted insertion, and the water exchange technique was not applied. Further studies here would help elucidate the effect of water-assisted techniques on colonoscopy-associated aerosol generation. Taken together with the predictable observation that longer procedures produce more particles, this is a further good reason for maintaining good colonoscopy technique, and may have implications for colonoscopy training, which would typically involve longer procedures and additional discomfort.

The most significant particle generating event in LGI endoscopy is rectal extubation, and in similarity to oesophageal extubation in UGI endoscopy, the average particle size is much larger 
medRxiv preprint doi: https://doi.org/10.1101/2021.04.15.21255544; this version posted April 20, 2021. The copyright holder for this preprint (which was not certified by peer review) is the author/funder, who has granted medRxiv a license to display the preprint in perpetuity.

It is made available under a CC-BY 4.0 International license .

than for volitional cough. Rectal extubation and intubation, and abdominal pressure application, produce comparable levels of particles to a volitional cough. Interestingly, for patients with high anal tone, abdominal pressure results in an increased number and average size of particles. This may be due to more air being held in the abdomen that is subsequently expelled under greater pressure.

In this study, we have characterised aerosol and droplet generation from the different routes of GI endoscopy. We recognise however, that this does not equate to infectivity of the procedures themselves. This depends on multiple factors, including which part of the patient the particles are being generated from; particles from the oral and nasal cavities are likely to have a much higher potential infectivity risk compared to those from the large bowel. As the infectivity of procedures is not established, we therefore suggest adequate PPE (including high-efficiency masks) is used for all GI endoscopy where there is a high population prevalence of COVID-19. The availability of reusable mask respirators, that have limited waste production and significantly lower cost, would represent a superior option to disposable FFP3 masks. PPE has been very effective in safeguarding healthcare workers in endoscopy and we must now look for PPE solutions that result in reduced cost and waste formation.

\section{CONCLUSION}

Our study shows endoscopic procedures performed via the mouth, nose or rectum all generate aerosols and droplets, and that individual events produce greater or comparable levels of particles compared to volitional cough. For UGI endoscopy, our results suggest aerosol generation can be greatly reduced by avoiding or finding alternatives to throat spray, and by performing TNE, but TNE is still an AGP and further mitigating strategies should be applied. LGI endoscopy produces more particles per procedure, but is less particle generating per unit time and produces more particles in the droplet range. The main contributing events are rectal extubation, application of abdominal pressure and rectal intubation. More studies are needed to evaluate mitigation strategies and to characterise the infectivity of these procedures themselves. 
medRxiv preprint doi: https://doi.org/10.1101/2021.04.15.21255544; this version posted April 20, 2021. The copyright holder for this preprint (which was not certified by peer review) is the author/funder, who has granted medRxiv a license to display the preprint in perpetuity. It is made available under a CC-BY 4.0 International license .

\section{CONTRIBUTORS}

FP, GSDG and APB designed the study. FP and APB performed many of the procedures. SW and JC collected and curated the data. GSDG statistically analysed the data. FP, GSDG and APB drafted the manuscript. All authors critically reviewed the manuscript.

\section{ACKNOWLEDGEMENTS}

The authors thank Guru Aithal for critically reviewing the manuscript; Martin James and Bu Hayee for reviewing the study protocol; Matthew Sanderson, Andy Wragg, Nottingham University Hospitals Research and Innovation, University of Nottingham Biomedical Research Centre, Karren Staniforth, Laura Leman, Nina Duffy, Allison Ball and the Endoscopy Unit Staff in their support of the development of this study; the NIHR Aerosol Generating Procedures Group for their support during the study; Tina Rodriguez, Paul Brocklebank, Mirela Pana, Sabina Beg, Stefano Sansone, James Catton, Emilie Wilkes, Lorraine Clark, Andrew Horton, John White, Suresh Vasan Venkatachalapathy, Aida Jawhari, loannis Varmpompitis, and Muthuram Rajaram for performing endoscopic procedures in this study; and Olympus for loan of the trans-nasal endoscopes

\section{FUNDING}

The authors also thank Nottingham University Hospitals NHS Trust for funding the rental of the N60 spray characteriser and rental of a particle counter, and Norgine Pharmaceuticals for sponsoring the purchase of a particle counter. GSDG would like to acknowledge a UKRI Future Leaders Fellowship (MR/T041951/1).

\section{COMPETING INTERESTS}

None declared.

\section{PATIENT CONSENT}

Obtained

\section{ETHICS APPROVAL}

Wales Research Ethics Committee

\section{DATA AVAILABILITY STATEMENT}

Data associated with this publication is available at http://dx.doi.org/10.17639/nott.7112 Code used for data analysis in this publication can be found at https://github.com/gsdgordon/aerosols 
medRxiv preprint doi: https://doi.org/10.1101/2021.04.15.21255544; this version posted April 20, 2021. The copyright holder for this preprint (which was not certified by peer review) is the author/funder, who has granted medRxiv a license to display the preprint in perpetuity. It is made available under a CC-BY 4.0 International license .

\section{REFERENCES}

1. Liu Y, Ning Z, Chen Y, Guo M, Liu Y, Gali NK, Sun L, Duan Y, Cai J, Westerdahl D, Liu X, Xu K, Ho KF, Kan H, Fu Q, Lan K. Aerodynamic analysis of SARS-CoV-2 in two Wuhan hospitals. Nature 2020;582(7813):557-60.

2. Fears AC, Klimstra WB, Duprex P, Hartman A, Weaver SC, Plante KS, et al. Persistence of Severe Acute Respiratory Syndrome Coronavirus 2 in Aerosol Suspensions. Emerg Infect Dis 2020;26(9):2168-2171.

3. Tang S, Mao Y, Jones RM, et al. Aerosol transmission of SARS-CoV-2? Evidence, prevention and control. Environ Int 2020;144:106039.

4. Wilson NM, Norton A, Young FP, Collins DW. Airborne transmission of severe acute respiratory syndrome coronavirus- 2 to healthcare workers: a narrative review. Anaesthesia 2020;75:1086-95

5. World Health Organization. Infection prevention and control during health care when coronavirus disease (COVID-19) is suspected or confirmed. Published June 29, 2020. https://www.who.int/publications/i/item/WHO-2019-nCoV-IPC-2020.

6. Wilson N, Corbett S, Tovey E. Airborne transmission of covid-19. BMJ 2020;370:m3206.

7. https://www.gov.uk/government/publications/wuhan-novel-coronavirus-infectionprevention-and-control/covid-19-infection-prevention-and-control-guidance-aerosolgenerating-procedures

8. Klompas M, Baker M, Rhee C. What Is an Aerosol-Generating Procedure. JAMA Surg 2021;156(2):113-114.

9. Gregson FKA, Watson NA, Orton CM, Haddrell AE, McCarthy LP, Finnie TJR, Gent N, Donaldson GC, Shah PL, Calder JD, Bzdek BR, Costello D, Reid JP. Comparing aerosol concentrations and particle size distributions generated by singing, speaking and breathing. Aerosol Science and Technology 2021

10. Tran K, Cimon K, Severn M, Pessoa-Silva CL, Conly J. Aerosol generating procedures and risk of transmission of acute respiratory infections to healthcare workers: a systematic review. PLoS One 2012;7(4):e35797.

11. https://www.bsg.org.uk/covid-19-advice/bsg-rationale-around-current-advice-to-allendoscopy-units/

12. Sultan S, Lim JK, Altayar O, Davitkov P, Feuerstein JD, Siddique SM, Falck-Ytter Y, El-Serag HB; AGA Institute. AGA Rapid Recommendations for Gastrointestinal Procedures During the COVID-19 Pandemic. Gastroenterology 2020;159(2):739-758.e4.

13. Gralnek IM, Hassan C, Beilenhoff $U$, Antonelli G, Ebigbo A, Pellisé $M$, Arvanitakis $M$, Bhandari P, Bisschops R, Van Hooft JE, Kaminski MF, Triantafyllou K, Webster G, Voiosu AM, Pohl H, Dunkley I, Fehrke B, Gazic M, Gjergek T, Maasen S, Waagenes W, de Pater M, Ponchon T, Siersema PD, Messmann H, Dinis-Ribeiro M. ESGE and ESGENA Position Statement on gastrointestinal endoscopy and COVID-19: An update on guidance during the post-lockdown phase and selected results from a membership survey. Endoscopy 2020;52(10):891-898.

14. Chiu PWY, Ng SC, Inoue H, Reddy DN, Ling Hu E, Cho JY, Ho LK, Hewett DG, Chiu HM, Rerknimitr R, Wang HP, Ho SH, Seo DW, Goh KL, Tajiri H, Kitano S, Chan FKL. Practice of endoscopy during COVID-19 pandemic: position statements of the Asian Pacific Society for Digestive Endoscopy (APSDE-COVID statements). Gut 2020;69(6):991-996.

15. Chan SM, Ma TW, Chong MK, Chan DL, Ng EKW, Chiu PWY. A Proof of Concept Study: Esophagogastroduodenoscopy Is an Aerosol-Generating Procedure and Continuous Oral Suction During the Procedure Reduces the Amount of Aerosol Generated. Gastroenterology 2020;159(5):1949-1951.e4. 
medRxiv preprint doi: https://doi.org/10.1101/2021.04.15.21255544; this version posted April 20, 2021. The copyright holder for this preprint (which was not certified by peer review) is the author/funder, who has granted medRxiv a license to display the preprint in perpetuity. It is made available under a CC-BY 4.0 International license .

16. Sagami R, Nishikiori H, Sato T, Tsuji H, Ono M, Togo K, Fukuda K, Okamoto K, Ogawa R, Mizukami K, Okimoto T, Kodama M, Amano Y, Murakami K. Aerosols Produced by Upper Gastrointestinal Endoscopy: A Quantitative Evaluation. Am J Gastroenterol 2021;116(1):202205.

17. Han ZY, Weng WG, Huang QY. Characterizations of particle size distribution of the droplets exhaled by sneeze. J R Soc Interface 2013;10(88):20130560.

18. Tang JW, Nicolle AD, Klettner CA, Pantelic J, Wang L, Suhaimi AB, Tan AY, Ong GW, Su R, Sekhar $\mathrm{C}$, Cheong DD, Tham KW. Airflow dynamics of human jets: sneezing and breathing - potential sources of infectious aerosols. PLoS One 2013;8(4):e59970.

19. Simonds AK, Hanak A, Chatwin M, Morrell M, Hall A, Parker KH, Siggers JH, Dickinson RJ. Evaluation of droplet dispersion during non-invasive ventilation, oxygen therapy, nebuliser treatment and chest physiotherapy in clinical practice: implications for management of pandemic influenza and other airborne infections. Health Technol Assess 2010;14(46):131172.

20. Morawska L, Johnson GR, Ristovski ZD, Hargreaves M, Mengersen K, Corbett S, Chao CYH, Li $\mathrm{Y}$, Katoshevski D. Size distribution and sites of origin of droplets expelled from the human respiratory tract during expiratory activities. J Aerosol Science 2009;40(3):256-269.

21. Brown J, Gregson FKA, Shrimpton A, Cook TM, Bzdek BR, Reid JP, Pickering AE. A quantitative evaluation of aerosol generation during tracheal intubation and extubation. Anaesthesia 2021;76(2):174-181.

22. Tan VYJ, Zhang EZY, Daniel D, Sadovoy A, Teo NWY, Kiong KL, Toh ST, Yuen HW. Respiratory droplet generation and dispersal during nasoendoscopy and upper respiratory swab testing. Head Neck 2020;42(10):2779-2781.

23. Xiao F, Tang M, Zheng X, LiU Y, Li X, Shan H. Evidence for gastrointestinal infection of SARSCoV-2. Gastroenterology 2020;158(6):1831-1833.e3.

24. Wang W, Xu Y, Gao R, et al. Detection of SARS-CoV-2 in different types of clinical specimens. JAMA 2020; 323:1843-1844.

25. Fuentes C, Parra V, Acero F, Gonzalez C, Aponte D, Sabbagh L. Protection barrier in colonoscopy to prevent transmission through feces in times of COVID-19. VideoGIE 2020;5(12):618621. 